\title{
焼結アルミニウム合金 $(\mathrm{SAP})$ の製造法に関する研究
}

\author{
增田 良 道* 田中英八郎** \\ 菊田貞雄** 德能裕已藤倉 正国***
}

Yoshimichi Masuda, Eihachiro Tanaka, Sadao Kikuta, Hiromi Tokuno and Masakuni Fujikura : On the Production Techniques of Sintered Aluminium Alloy.

Each process of production techniques of sintered aluminium alloy was studied experimentally by using atomized aluminium powder as starting material. The optimum condition was determined for each process in regarding with the properties of produced alloys.

The results obtained are as following:

(1) The optimum pressure for powder compaction at room temperature was 5 ton $/ \mathrm{cm}^{2}$ in taking account of densification and crack formation in compact. At this pressure the powders containing $10 \sim 15 \mathrm{wt} \%$ oxide were compacted to a density of $2.2 \sim 2.5 \mathrm{~g} / \mathrm{cm}^{3}$, with a compacting factor of $3.0 \sim 3.5$.

(2) In extrusion of the hot pressed compact much sounder material of uniform density was produced than in that of the cold compacted powder using the lower extrusion ratio, although the extrusion pressure increased about $10 \%$.

(3) In order to prevent the occurence of defects in the extruded products it is preferable to use of conical die designed to be minimized the shear component in material flow.

(4) For leveling down of the extrusion pressure the using of appropriate lubricant and the higher extrusion speed is advantageous.

As the hot pressed compact containing $11.6 \mathrm{wt} \%$ oxide was extruded at $500^{\circ} \mathrm{C}$ by using a 15: 1 ratio and a lubricant of colloidal graphite in extrusion speed of $47 \mathrm{~mm} / \mathrm{sec}$, the extrusion pressure became lower than $40 \mathrm{~kg} / \mathrm{mm}^{2}$.

\section{(Received August 30, 1963)}

\section{I. 緒 謇}

アルミニウムとアルミナの 分散型合金であるSAP につ いては,すでに数多くの研究が行なわれている(1)〜(3)†. と くに常温执よび高温に拁けるその機械的性質については多 くの実験が行なわれ(4)〜(14)，いわゆる分散強化機構につい ては理論的検討も行なわれた(11)(12). その結果, SAP の機 械的性質と分散相の分布状態については, 一定の関係が存

* 東北大学工学部金属工学科 (Department of Metallurgy, Faculty, of Engineering, Tôhoku University, Sendai)

** 東北大学金属材料研究所 (The Research Institute for Iron, Steel and Other Metals, Tôhoku University, Sendai)

*** 日本楽器製造株式会社 (当時) (Nippon Musical Institute Mfg. Co. Ltd., Hamamatsu)

(1) J.G.Solomir: Z.Metallk., 52 (1961) , 1645.

(2) E.M.Modl-Onitsch: Aluminium, 37 (1961), 724.

(3) E. A. Bloch and H.Hug: W. Leszynski eds., Powder Metallurgy, (1961), Interscience Puk1. N.Y., 371.

$\dagger(1),(2),(3)$ はAP に関する最近の輯録文献

(4) A. von Zeerleder: Z.Metallk., 41 (1950),228.

(5) E.Boenisch and W.Wiederholt: Z.Metallk., 42 (1951) , 344 .

(6) R.Irmann: Metallurgia, 46 (1952), 125.

(7) E.Gregory and N.J.Grant: Trans. AIME, 200 (1954),247.

(8) F.V.Lenel, A. B..Backensto and M.V.Rose: Trans. AIME, 209 (1957), 124.

(9) F.V.Lenel: R.F.Hehemann, G.M.Ault, eds., High Temperature Materials, Wiley, N. Y., (1959) , 321.

(10) G.S.Anseli: Trans. AIME, 215 (1959), 294.
在することが明らかにされ，またその機械的性質の一部に ついてはある程度理論的説明も可能になつている. しか し, SAP の製造工程はきわめて複雑で, 製粉, 成形および 押出し加工の各段階に括いて, 分散相の分布状態を制約す る要素が多数存在する.したがつてこのような製造工程を 経て作られたSAP の機械的性質は，各段階に括ける製造 条件によつて当然なんらかの影響をうけると考えられる。 しかしSAP 亿関する従来の研究はいずれるその特性自体 を対象としたものが多く，製造工程を主体とした研究や， またとれと性質との関連性を対象とした研究はほとんど発 表されていない，われわれはこの観点から，SAPについて 粉末の調製からその諸特性の研究にいたるまで一貫した研 究を行ない，主としてその製造条件と性質との間の関係を 明らかにする目的でこの研究を行なつた。な报，本報では まずこの研究の第一段階としての製造工程について, 各段 階における製造条件や加工法の検討を行なつた結果を報告 し, これと関連する諸性質の研究結果については別報で報 告する.

(11) G.S.Ansell and J.Weertman: Trans. AIME, $215(1959), 838$.

(12) F.V.Lenel and G.S.Ansell: W.Leszynski eds., Powder Melallurgy, Interscience Publ. N. Y., (1961) ,267.

(13) E.J.Westerman and F.V.Lenel: Trans. AIME, $218(1960), 1010$.

(14) C.L.Meyers and O.D.Sherby: J.Inst. Metals, $90(1961 \sim 2), 380$. 


\section{II. 実 験 方 法}

\section{1. 粉末 $の$ 調製}

原料粉末は市販のアトマイズ $\mathrm{A} 1$ 粉(15)を使用した。その 純度および主な性質はTable 1 に示したと拈りで，酸素 は $\mathrm{Al}_{2} \mathrm{O}_{3}$ として約 $0.5 \mathrm{wt} \%$ であつた，従来の SIAG 法に 準拠し(6)，これにステアリン酸を $0.5 \mathrm{wt} \%$ 添加し，シャ ワー型ボールミル(16)を使用して, 酸素を 8 vol\% 含む酸素 と窒素の混合気流中で粉砕し，酸化物含有量を調整した。

Table 1 Atomized aluminium powder used for raw materials of SAP.

\begin{tabular}{c|c|c|c|c|c}
\hline $\begin{array}{c}\text { Mesh or } \\
\text { particle size }\end{array}$ & $\begin{array}{c}\text { Tap } \\
\text { density } \\
\text { (g/cc) }\end{array}$ & \multicolumn{3}{|c}{ Chemical analysis, wt\% } \\
\cline { 2 - 6 } & $\mathrm{Fe}$ & $\mathrm{Si}$ & $\mathrm{Cu}$ & $\begin{array}{c}\mathrm{O}_{2} \\
\left.\text { (as } \mathrm{Al}_{2} \mathrm{O}_{3}\right)\end{array}$ \\
\hline $\begin{array}{c}-200 \text { mesh } \\
<74 \text { microns }\end{array}$ & 1.0 & 0.8 & 0.3 & 0.3 & 0.52 \\
\hline
\end{tabular}

原料粉末の粒形はPhoto.1 (a) に示したように液滴形で あるが (Photo.1)，粉砕の進行に伴なつて (b)のように鱗片 形となり，さらに粉䂗が進むと微細化すると同時に一方で は徐々に凝集が扣こり，(c)に示したような粒状の 粉末に なる.このような粒形の変化に伴なつて粉末の性質は当然 著しく変化する．Fig.1はその一例を示した図で，粉砕時 間に対して粉末中の酸化物量, および粉末のタップ密度と 被覆面積が変化する (Fig.1)． 粉末粒子が鱗片状になると

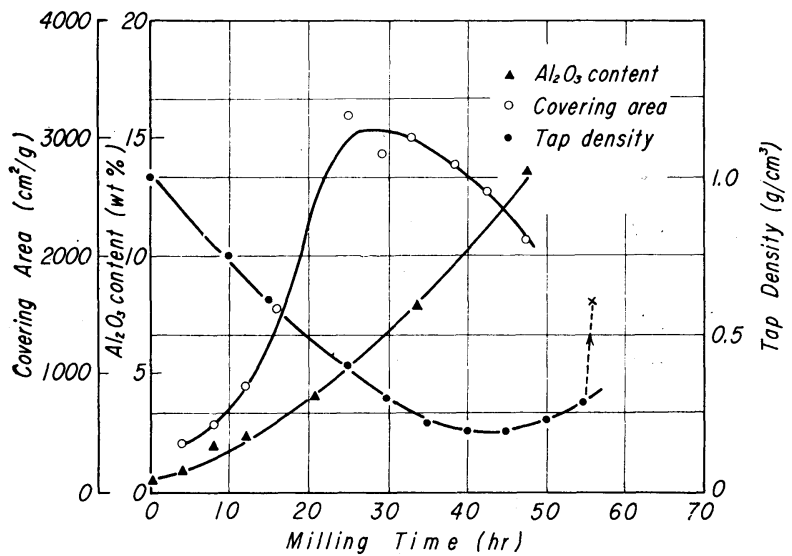

Fig.1 Change in properties of aluminium powder during a milling process.

表面張力で水面に浮くよ5になるので, 単位質量の粉末が 水面を被覆する面積を測定し，被覆面積を求めた(17)。すな わちこの場合被覆面積は粉碀過程を知るために一つの目安 となる．この図からわかるように，粉末中の酸化物は粉砕 時間とともに増加するが，被覆面積と密度は粒子の凝集が 始まると急激に変化する．すなわち被覆面積は極大值を経

(15) 長谷川，今村：金属学会会報, 1 (1962),263.

(16) F. Skaupy : Metallkeramik, Verlag Chemie, Weinheim, Bergstr, (1950) ,224.

(17) J.D.Edwards and R.D.Mason: Ind.Eng.Chem. Anal.Ed., 6(1934), 159 .
て急激に減少し, 密度は逆に極小值を経て増加するが，そ の時期はやや遅れる。この実験例では, 凝集は粉研開始か

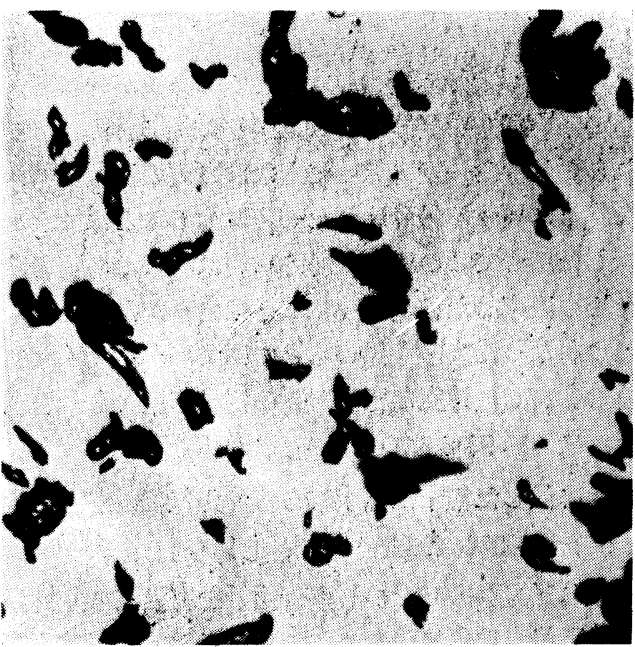

(a) as atomized

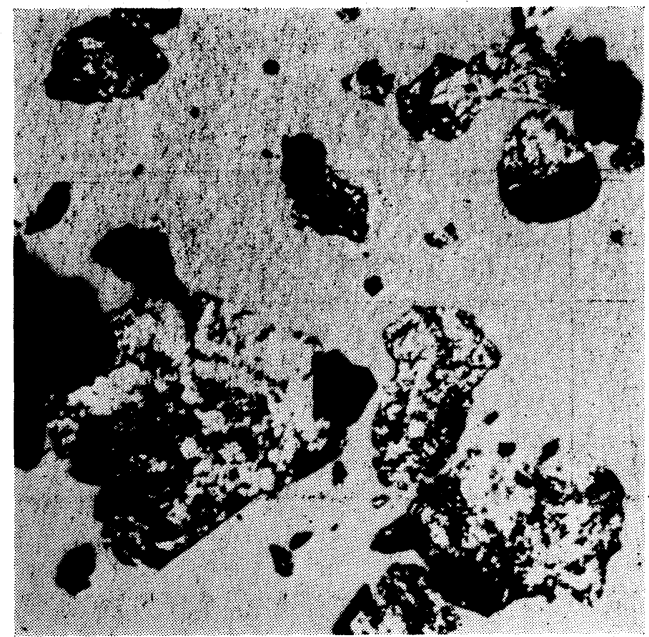

(b) milled

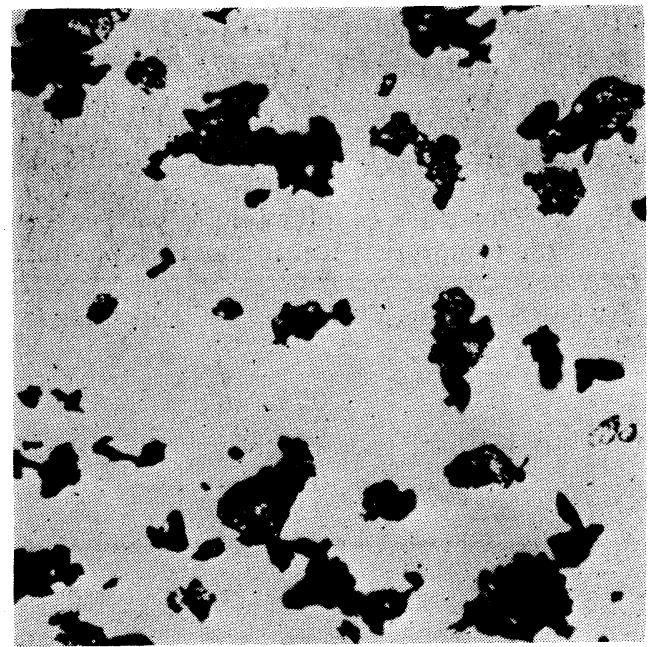

(c) milled and granulated

Photo.1 Various sort of aluminium powder. $(\times 250)$ 
ら約 30 時間後に拈こつているが，その時期は粉啸条件と くに粉碎機の構造や機能, さらに雾囲気, 凝集防止剤の添 加量によつて変化する．たとえば，ステアリン酸の添加量 や雲囲気中の酸素量が前記の值よりも少ない条件で粉确す ると, 粉砩が十分に進行しないらちに凝集が扣こり，酸化 物量の多い粉末を調製することが不可能であつた。しかし これらの条件を一定に保つてもな招所要の性質を備えた粉 末を作るに要する粉确時間を一定にすることはできなから た.したがつてこの場合，粉确時間は粉末の性質を調整す るための決定的な目安とすることはでさなからたが，われ われの行なつた実験条件のもとでは 10 15 wt％ 程度の酸 化物を含有し，適度な密度および，成形性をるつ粉末を作 るには約 40〜50 時間を要した.

実験に供した粉末はいずれも粉硡処理後, 真空中 $\left(10^{-3}\right.$ $\mathrm{mmHg}$ )で $400^{\circ} \mathrm{C}$ に 1.5 時間加熱し,添加したステアリン酸 を十分に蒸発除去したのち酸化物量を塩素法で分析した。 また脱脂後の粒化処理によつて粉末のタップ密度は Fig.1 に×印で示したように，処理前の 值約 0.25 から $0.6 \mathrm{~g} / \mathrm{cc}$ 位まで飛躍的に增加し，吸着物質の離脱と同時に粒子の凝 集が促進するごとを認めた。
トの素材を作るために用いたものと同じである．図に示し たように压粉体の高さ $H$ の変化,すなわちラムの行程に対

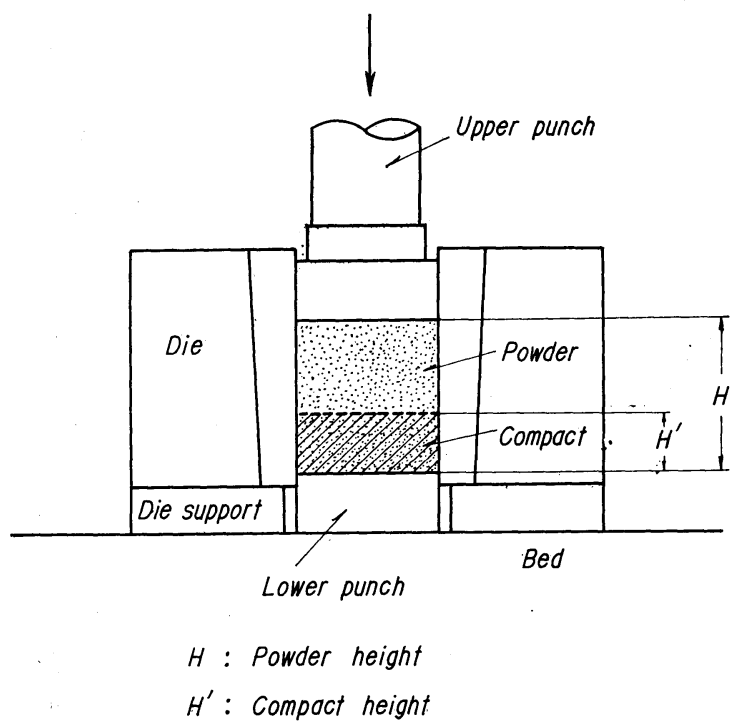

Fig.2 Die arrangement used for cold compacting of aluminium powder.

Table 3 Methods and conditions of extrusion experiment.

\begin{tabular}{|c|c|c|c|c|c|}
\hline \multirow{2}{*}{ Series } & \multirow{2}{*}{$\begin{array}{l}\text { Diameter of green } \\
\text { compact used for } \\
\text { billet }(\mathrm{mm})\end{array}$} & \multirow{2}{*}{$\begin{array}{l}\text { Sheathing for hot } \\
\text { compact and billet }\end{array}$} & \multicolumn{3}{|c|}{ Extrusion } \\
\hline & & & $\begin{array}{c}\begin{array}{c}\text { Diameter of container } \\
(\mathrm{mm})\end{array} \\
\end{array}$ & Method & Press \\
\hline A & 19 & $\begin{array}{l}\text { W rapped with } \mathrm{Al} \\
\text { foil }\end{array}$ & 20 & direct & Vertical type $40 \mathrm{t}$ \\
\hline $\mathrm{B}$ & 30 & " & 32 & indirect & " \\
\hline $\mathrm{C}$ & 62 & $\begin{array}{l}\text { Packed in A1-can } \\
\text { of } 3 \mathrm{~mm} \text { chick }\end{array}$ & 75 & " & Horizontal type $300 \mathrm{t}$ \\
\hline
\end{tabular}

\section{2. 常温王粉成形}

压縮成形の第一条件として適当な成形王力を決定するた め, Table 2 に示した酸化物の含有量の異なる 4 種の粉 末について常温に和ける王縮成形試験を行なつた。すなわ ち, 粉末 No.1,2,3,4を選び，それらの粉末約 $1 \mathrm{~g}$ を直径 $10 \mathrm{~mm}$ の円筒形金型 (スプリング浮型方式) で圧縮成形し, それぞれの成形任力に対して得られた圧粉体の密度を測定

Table 2 Properties of aluminium powder used for compaction test in room temperature.

\begin{tabular}{c|c|c|c}
\hline $\begin{array}{c}\text { Powder } \\
\text { No. }\end{array}$ & $\begin{array}{c}\mathrm{Al}_{2} \mathrm{O}_{3} \text { content } \\
\text { (wt } \%)\end{array}$ & $\begin{array}{c}\text { Tap density } \\
\left(\mathrm{g} / \mathrm{cm}^{3}\right)\end{array}$ & $\begin{array}{c}\text { Compacting facter } \\
\text { at }\left(5 \mathrm{t} / \mathrm{cm}^{2}\right)\end{array}$ \\
\hline 1 & 3.1 & 0.71 & 3.6 \\
2 & 7.6 & 0.77 & 3.2 \\
3 & 10.7 & 1.07 & 2.2 \\
4 & 15.8 & 0.66 & 3.4 \\
5 & 16.4 & 0.81 & 3.0 \\
\hline
\end{tabular}

した・なおまた圧縮成形の過程を詳細に調べる目的で圧縮 時に括ける圧力の変化を測定する実験を行つた．ただしこ の実験には粉末 No.5を用い, Fig. 2 に示したような片押 し方式の円筒金型を使用した.この金型は押出し用ビレッ
する圧縮圧力の変化を測定した．また，常温圧粉の実験に はすべて潤滑剤としてパラフィンの四塩化炭素溶液を工具 面に塗布し, 粉末と工具との摩擦および粘着を防いだ。

な扮押出し実験用の試料としては Table 3 に示したよ うな直径の異なる 3 種の圧粉体を調製した。これらはいず れも $5 \mathrm{t} / \mathrm{cm}^{2}$ の生力のもとに $10 \sim 30 \mathrm{sec}$ 保持し王縮成形し たが，これらの条件は前記の圧縮成形試験の結果から決定 した (III.2.参照).

\section{3. 高温王縮 成 形}

常温で王縮成形した圧粉体をそのまま高温押出しにかけ ることは不可能ではないが，予め高温で王縮成形すれば押 出材の密度や分散度は一層高くなることが期待される.し たがつて, 両者を比較検討寸るために高温生縮体の押出し 試験も行なつた.な抗のための試料は Table 3に示した 3 種の大きさの異なる圧粉体を用いて製作した．その場合 王粉体はいずれるその両端面をブラッシングしたのち数個 重ね合せ, A,Bの場合はアルミニウム䇴で包み, Cの場合 は肉厚 $3 \mathrm{~mm}$ のアルミニウム円筒に詰め $500^{\circ} \mathrm{C}, 5 \mathrm{t} / \mathrm{cm}^{2}$ で 圧縮加工を行なつた。この条件はできるだけ密度の高い 
わのを得る目的で，耐熱鋼金型の耐熱限度を考兄に入れ て選んだ.な叔，この場合の潤滑剂はコロイド黑鉛㲘渴油 (oildag)を用いたまたこの処理によつて压縮体の常温圧 粉体の密度の約 1.2〜1.3 倍となり, 袹押出し材の值に 近くなつた.

\section{4. 高温押出 ᄂ}

高温押出しの実験に供した王粉体，括よび高温圧縮体は いずれも前記の万法および条件によつて製作したるのであ るが, 高温压縮成形体は表面の被覆材を切削除去したの ちふふたたびアルミニウム被覆を行なつた。

押出し装置は Fig.3 亿Aの場合を示し，李たBの場合は $\mathrm{A}$ と同形式のむのをダミイ・ブロックとダイスを逆に入 れ換えて用いた。な技，Cの場合はFig.4に示した横型

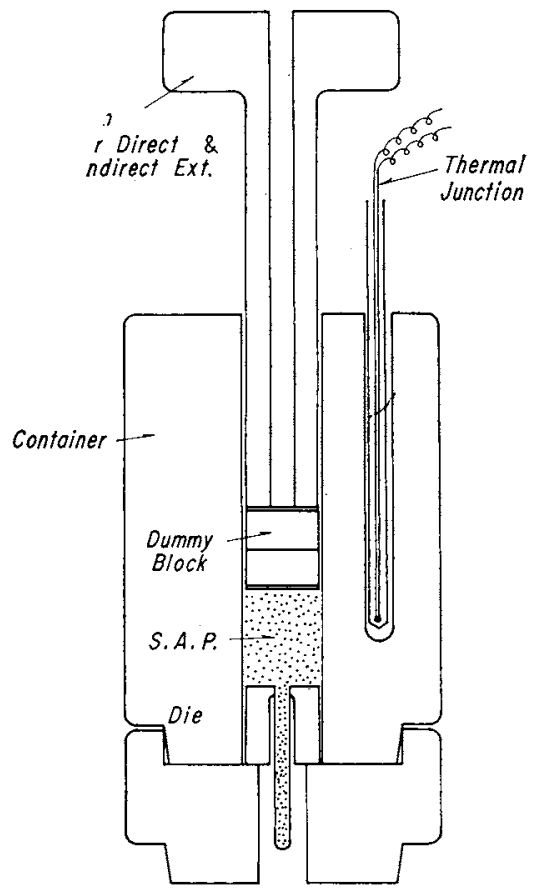

Fig.3 Schematic diagram of die assembly for direct extrusion.

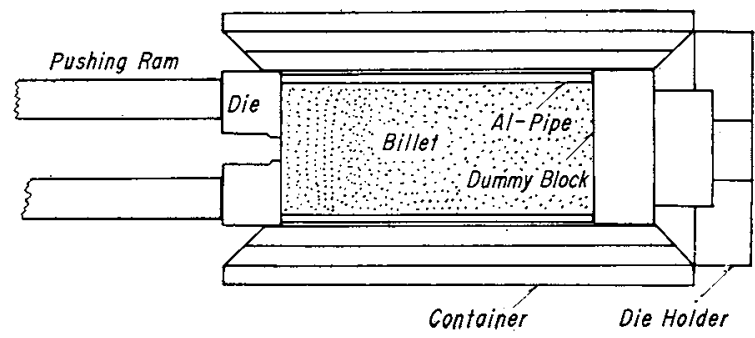

Fig.4 Schematic diagram of die assembly for indirect extrusion.

の押出し装置を用いた。また使用した押出し機妒 Table 3 に示したよ 5 にそれぞれ $40 \mathrm{t}$ の堅型执よび $300 \mathrm{t}$ の横型水 压機を用い，压力の測定は前者の場合支柱に貼りつけた抵 抗線䨤計を，また後者では水殴計を用いた。
押出し条件のうち温度は $500^{\circ} \sim 550^{\circ} \mathrm{C}$ の間に限定した が，この条件は别の押出し材沉ついて高温王維試験を行な つた結果から決定した。なおこの実験については別報で報 告する，その他押出し素材，押出し方法，潤滑凧の種類， 速度，ダイスの形状，材質などを变え，押出圧の变化を測 定した。

\section{III. 実 験結 果とその考察}

1. 常温圧粉体の密度と成形印力の関保

酸化物含有量の異なる 4 種の粉末について, 成形区力と 厈粉体の密度の関係を図示すると Fig.5のようになる。一

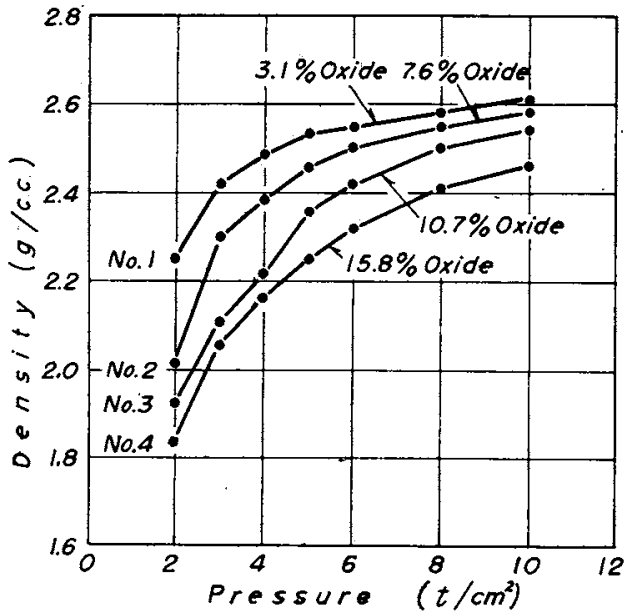

Fig.5 Relation between compacting pressure and density of green compact of various aluminium powder with different oxide content.

般的傾向は普通の純金属粉末の場合と比べてとくに変つた 点は認められない，また当然のことながら，酸化物含有量 の多い粉末汪ど王縮性が惠く，圧粉体の密度は粉末の酸化 物含有量と正粉圧力によつてをまり, 生粉以前の粉末の見 かけ密度とは直接関係がない，この場合粉末の真密度を正 確に測定することができないので王粉体の密度比ないし充 実度を求めることはできないが，押出し材の密度に対する 百分率を求內てみると，10 t/ $\mathrm{cm}^{2}$ で成形した圧粉体の密度 は 90〜95\% 程度となる. Fig. 5 からわかるよ 3 に $8 \mathrm{t} / \mathrm{cm}^{2}$ 以上の圧力で冉粉しても密度の增加はたいして期待でき ずまた五力が高くなると潤滑剤を用いても型の壁面に対 する粉末の粘着が著しく，王粉体を型から押出すとき層状 に破壞する．したがつて余り高地力で成形することは実際 上好ましくない，一方圧力が $2 \downarrow / \mathrm{cm}^{2}$ 以下の場合梳粒化度 の低い鳞片状粒子を多く含む粉末は成形が困難である，以 上の実験結果敊よび実際的見地からみて，常温に括ける圧 縮成形の圧力は $5 \mathrm{t} / \mathrm{cm}^{2}$ が適当と考党られる.したがつて 正粉体の密度は $2.2 \sim 2.5 \mathrm{~g} / \mathrm{cc}$ 程度となる.

\section{2. 常温仕粉通程と粉末是との関係}

Fig.6は同一ロットの粉末(Table 2,No.5) Kついて粉 


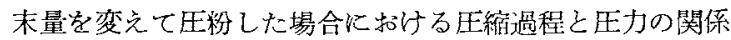
を示した図である。すなわち，横蚰に正縮時におけるラム

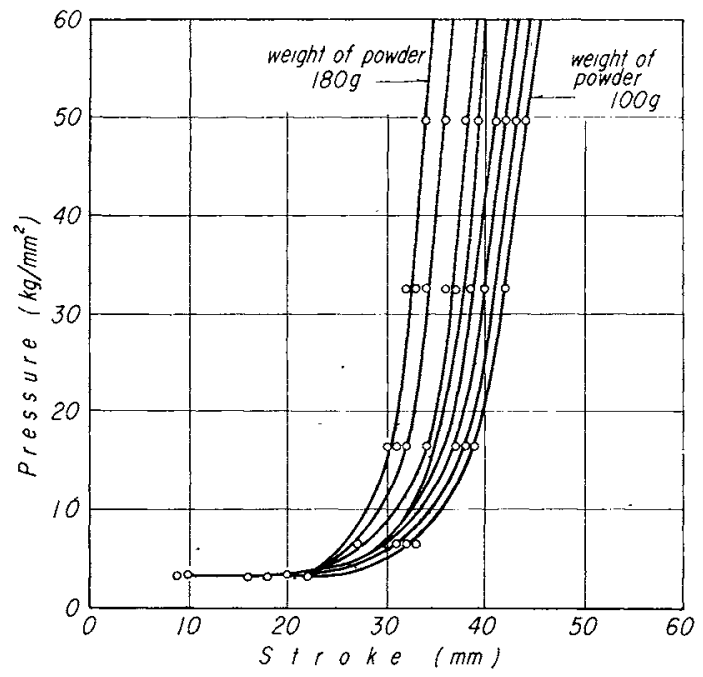

Fig. 6 Changes in pressure with increasing of ram stroke during compacting various amount of aluminium powder containing 16.4 wt \% $\mathrm{Al}_{2} \mathrm{O}_{3}$ in room temperature.

ないしパンチの行程をとり，維軸汇在力の上昇を示した。 いずれの場合も圧力は压縮過程の初期火㧊いてては低く，注 ぼ一定であり終期侄つて急激兽加する。この曲線の形 は润滑剂の有無によつては変化しないが，粉末量が異なる と压粉体の高さが当然墥つて来るので，図中炕示したよう に变化する。しかしこの実験に用いた正粉装置 (Fig.2)の 場合，粉末量を $100 \sim 300 \mathrm{~g}$ の範围にと々，最終王力を $5 \mathrm{t} /$ $\mathrm{cm}^{2}$ とすれば，円柱王粉体の膏さは 15 40 mm 程度とな ク，この範囲で性粉末量と王粉体の高さの関係结 Fig.7 K

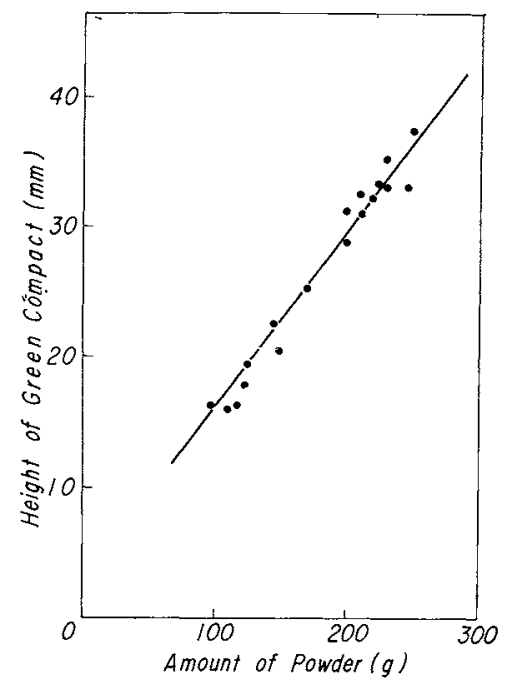

Fig.7 Relation between height of cylindrical compact and amount of powder used.

示したように活添直線となり，得られる压粉体の密度は汪 ぼ二定 $(2.45 \mathrm{~g} / \mathrm{cc})$ になることがわからだしたがうてこ
の場合粉末の圧縮比は約 3:1 火なる.

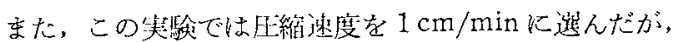
この程度の低速で正縮成形を行な光ば，鼠終生力 $5 \mathrm{t} / \mathrm{cm}^{2}$

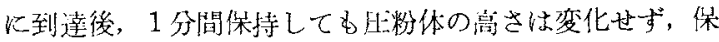
持時間に対しては䌿とんど無関倸となる。

\section{3. 正粉体の高温压縮過程}

Fig.8 妒酸化物含有量の異なる数種の因粉体について高 温压縮 $\left(500^{\circ} \mathrm{C}, 5 \mathrm{t} / \mathrm{cm}^{2}\right)$ 実騟を行なつた結果を示した图で 古る(Fig.8)。すなわち，横軸に压縮体の長さないし高さ の減少をとり，縦軸に压縮過程に括ける王力の变化をと り，'各試料の正縮過程を示した。この寒験化供した圧粉体 試料はいずれも同一条件で调製 (Table 3C) したものであ るが，この図からわかる上らにそれらの正繀過程は必ずし も同一ではない（a）は比較的正常な維過程の場合で， 压力は圧縮過程の進行に伴なって2段階に增加する。すな わち，この場合円柱形の法粉体試料の直径恃压縮成形の金 型の内径に比へてやや小さく，最小約 $1 \mathrm{~mm}$ の苏とびがあ る. したがロて第 1 段のE力上萛は压粉体か降伏するまで

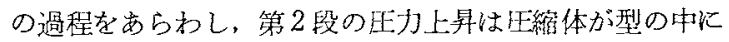

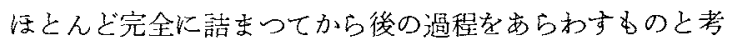
光られ，この場合は普通の金属円柱老正繀成形した場合の 過程と同じである。一方(b)に示した例な巽常な区縮過程!

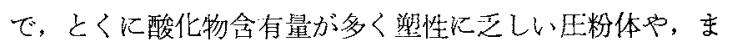
た試料と型の閒のあそびが大きい場合におこりがちであ る、すなわち，(a)に示した例はいずれる酸化物量が 10 $\mathrm{wt} \%$ 前後の圧粉体を用いた場合で，この程度の酸化物空 の場合はほぼ正常な不維過程を呈するが，酸化物量が 15 wt％前後になると (b) に示したように異常過程を示す。

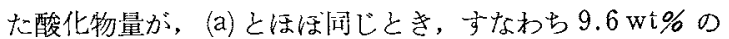
試料で径が型の径比比て著しく小さいために異常上緶 過程を扎こした例である。このよらな異常を呈する原因は

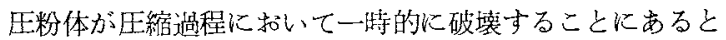
考光られるが，医維過程が異常を呈してる，压維の条件が 一定ならばほぼ一定の密度の圧維体が得られる。この場合 得られる压縮体密度の䋓対值はるち万ん酸化物含有量や压 縮条件炕左右されるが，500 $\mathrm{C}, 5 \mathrm{t} / \mathrm{cm}^{2}$ で压縮した場合， 正粉体加正縮体への実質的な”体嫧減少摔は䄪 $15 \%$ て。, 密度も体積減少见相当するだけ增加し，押出し材の密度の 健に近いるのとなった。

\section{4. 正押出し過程における押出し圧力と 潤滑郕および押出し速度の関係}

SAP の高温押出しに適した潤滑剂拈よび押纯し速度を 決定するため，できるだけ他の条件を一定に保つて正押出 しの実験を行ない，押出し无力におよぼす润滑剤や押出し 速度の影響を調べた。すなわち, Table 4 は酸化物含有量 $11.6 \mathrm{wt} \%$ のA型試料 (Table 3 参照) 飞ついて, flat die (bearing length $2 \mathrm{~mm}$, 押出し比 15:1) を用い, 正押出 しを行なつた結果をまとめたるのである。な物この場合， 
押出し温度は $500^{\circ} \mathrm{C} を$ 目槽とし，できるだけ一定に保つよ ろに努めたが, 予䓡の温度調整が難かしく, その結果は表
下するためと考えられる。しかしこの点はな扔検討を要す るので,ここでただちに結論することは避けたい。しかし
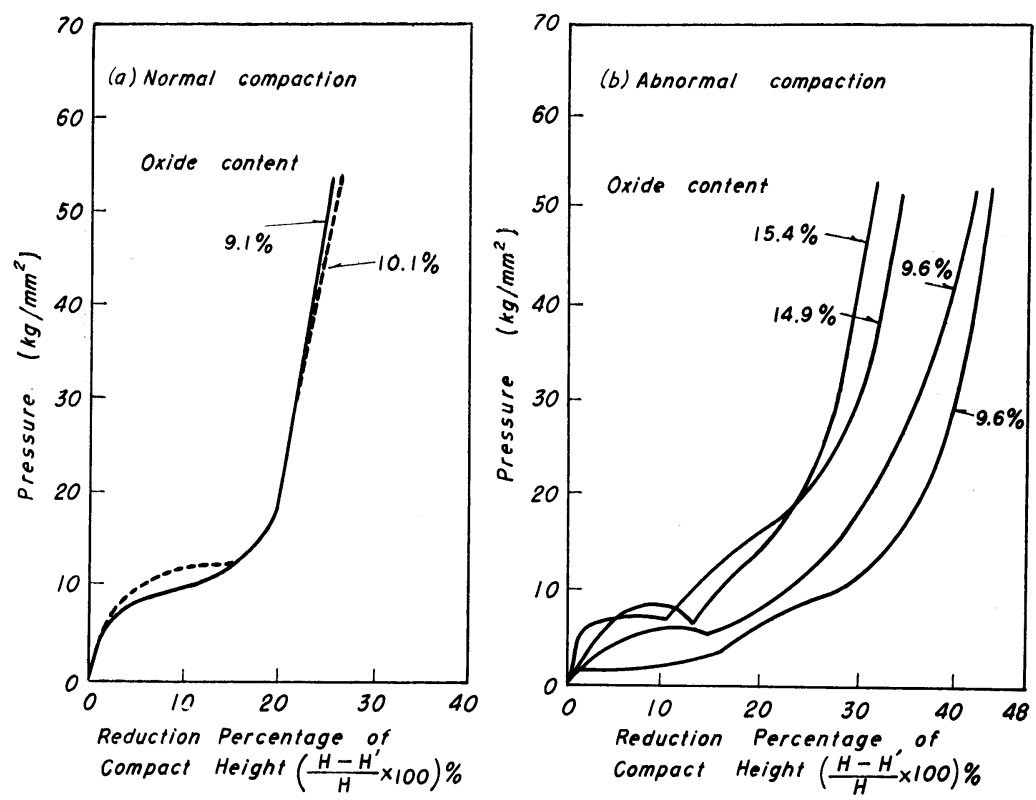

Fig. 8 Changes in pressure with increase in reduction percentage of compact height during hot pressing of various green compacts containing different $\mathrm{Al}_{2} \mathrm{O}_{3}$ amount.

Table 4 Experimental conditions for direct extrusion of A series shown in Table 3.

\begin{tabular}{c|c|c|c|c|c}
\hline & Lubricant & Temp. $\left({ }^{\circ} \mathrm{C}\right)$ & Speed $(\mathrm{mm} / \mathrm{sec})$ & Press $\left(\mathrm{kg} / \mathrm{mm}^{2}\right)$ & Miscellaneous \\
\hline 1-0 & no Lubrication & 503 & 25 & 58.5 & Oxide Content 11.6 wt \% \\
$1-1$ & Graphite Grease & 496 & 21 & 55.1 & Cold Press Compact \\
$1-2$ & " & 490 & 46 & 43.0 & $18 \mathrm{~mm} \times 38 \mathrm{mmh}$ \\
$2-1$ & Moly kote & 508 & 23 & 57.1 & Direct Ext. \\
$2-2$ & "k & 533 & 34 & 43.4 & Ext. Ratio 15 \\
$2-3$ & " & 510 & 47 & 47.3 & Flat Die \\
$3-1$ & Aqua-dag & 506 & 21 & 42.1 & Bearing Length $2 \mathrm{~mm}$ \\
$3-2$ & " & 500 & 39 & 40.1 & \\
$4-1$ & Oil-dag & 495 & 45 & 48.4 & \\
$4-2$ & " & 506 & 47.4 & \\
\hline
\end{tabular}

に記載したようにやや不同となつた。したがって，以下実 験結果の検討汇際しては,できるだけ相互の.1度差の小さ いものを選んで比較した.さて,この表からわかるよ5に 無潤滑の場合 (1-0), 押出し速度 $21 \sim 25 \mathrm{~mm} / \mathrm{sec}$ で押出し 圧は $58.5 \mathrm{~kg} / \mathrm{mm}^{2}$ となり，かなり高いが，照鉛グリース のような普通の潤滑剂を試料塗布すると押出し圧は数\% 低下し， $55.1,57.1 \mathrm{~kg} / \mathrm{mm}^{2}(1-1,2-1)$ 程度になる。また， さらにコロイド黒鉛懸濁水のような特殊潤滑剤を用いた場 合 (3-1)，押出し压は約 $30 \%$ も低下し $42.1 \mathrm{~kg} / \mathrm{mm}^{2}$ とな つた.

一方，同じ潤滑剤を使用し，押出し速度を変化させた場 合, すなわち 1-1 と 1-2,2-1 と 2-3, 3-1 と 3-2,4-1 と 4-2 をそれぞれ比較してみると，明らかに押出し速度の大きい 方が押出し圧が低いことがわかる．この傾向は普通の金属 の押出しの場合とは全く逆で, SAP の特徵の一つと考元 られる。また，その原因は押出し速度が大きくなると押出 し中に温度上年が扢こり，そのためSAP の変形抵抗が低
以上の結果から SAP の高温に扔ける押出し 圧は本来かな り高いにもかかわらず，潤滑剤や押出し速度の適当な選定 によって相当低い值, たとえば $40 \mathrm{~kg} / \mathrm{mm}^{2}$ 以下 (4-2) に下 げうることが明らかにされた。

\section{5. 逆押出し過程における圧カの変化}

逆押出し過程に捺けるラム行程と圧力の変化との関係は 普通の金属の場合とほとんど同様で，とくに指摘すべき特 徵はない，すなわち，押出し開始後圧力はほとんど一定で 変化なく，その圧力は同一条件で正押出しを行なつた場合 に比較して低い。

\section{6. 常温圧粉体の押出し加エ}

常温で成形した压粉体を高温圧縮せず，そのまま高温押 出しした場合と，高温压縮成形を行なつたのち押出した場 合と両者を比較するため, 酸化物量の同じ試料について, できるだけ押出し条件を同じにして比較実験を行なつた。 
その結果はTable 5 に示したように正，逆いずれの 押出 しの場合にも，素材に圧粉体を用いた場合は高温圧縮体を
認められない。また 3,4 および 5,6 はいずれも flat die で材質はそれぞれ SKD 4 (ダイス鋼) と超硬合金 (WC-Co)

Table 5 Relation between extrusion pressure and content of oxide in billets (prepared by two diffrent method).

\begin{tabular}{|c|c|c|c|c|c|c|c|c|}
\hline & $\begin{array}{l}\text { Oxide content } \\
(\text { wt } \%)\end{array}$ & $\mathrm{C}$ or $\mathrm{H}$ & Direct or Indirect & $\begin{array}{l}\text { Ext. Ratio } \\
(\mathrm{mm} \phi)\end{array}$ & $\begin{array}{l}\text { Ext.Temp. } \\
\text { (g) }\end{array}$ & $\begin{array}{c}\text { Speed } \\
(\mathrm{mm} / \mathrm{sec})\end{array}$ & $\begin{array}{c}\text { Press } \\
\left(\mathrm{kg} / \mathrm{mm}^{2}\right)\end{array}$ & Die \\
\hline 1 & 9.6 & C & Indirect & $10(10)$ & 509 & 24 & 30.0 & $\begin{array}{l}\text { Flat die } \\
\text { bearig } 2 \mathrm{~mm}\end{array}$ \\
\hline $\begin{array}{l}2 \\
3 \\
4 \\
5 \\
6 \\
7\end{array}$ & $\begin{array}{l}\text { "1 } \\
\text { "1 } \\
\text { 7.6 } \\
\text { "1 }\end{array}$ & $\begin{array}{l}\mathrm{C} \\
\mathrm{C} \\
\mathrm{H} \\
\mathrm{H} \\
\mathrm{C} \\
\mathrm{H}\end{array}$ & $\begin{array}{c}\text { "' } \\
\text { "' } \\
\text { "Irect } \\
\text { " }\end{array}$ & $\begin{array}{l}10(10) \\
10(10) \\
10(10) \\
10(10) \\
15(5) \\
15(5)\end{array}$ & $\begin{array}{l}511 \\
509 \\
510 \\
500 \\
513 \\
505\end{array}$ & $\begin{array}{r}8 \\
5 \\
14 \\
7 \\
30 \\
28\end{array}$ & $\begin{array}{l}35.0 \\
40.5 \\
34.0 \\
38.0 \\
45.5 \\
50.0\end{array}$ & $\begin{array}{l}\text { "1 } \\
\text { "1 } \\
\text { "1 } \\
\text { "1 }\end{array}$ \\
\hline
\end{tabular}

C: Cold pressed billet ; $\mathrm{H}:$ Hot pressed billet $\left(500^{\circ} \mathrm{C}, 5 \mathrm{t} / \mathrm{cm}^{2}\right)$

用いた場合に比べて押出し压は約 10\% 低い $(6,7,2,5$ 参 照)。これは拈そらく粉末粒子間の 結合状態の差に原因す ると思われる.しかし，この点についてはな扔今後の研究 にまたなければならない。

一方, 圧粉体と高温圧縮体の密度差は $12 \%$ であつたが, これらを押出したものの密度にはほとんぞ差がなかつた。 したがつて, 压粉体に存在した空吵は押出し加工中にほと んど絞り出されてしま5すのと考えられる．また，そのた めか押出し材の末端近くに空気の吹出し口と思われるフク レを生じ，その近傍はきわめて多孔質となる。

さらに王粉体を素材とした押出し材に扔いては, その末 端部に細かい亀裂が多数発生するが, これはコンテナー中 の dead metal 飞相当する部分と推定される.

以上の結果から, 压粉体をそのまを素材として押出せば 押出し圧は低くてすむが, その押出し材は高温圧縮体を素 材としたものに比べて末端部に種々の欠陥があらわれやす く、また, 密度す不均一になる持それがあることがわかつ た.

\section{7.押出し圧におよばすダイスの 形状および材啠の影響}

A 抢よび B 型の試料 (Table 3 参照)について, 形状拉よ び材質の異なる種々のダイスを用い逆押出しの実験を行な い,その結果を Table 6 亿まとめた.
であるが，押出し圧は超硬ダイスのオがやや高い程度で， いずれにしても大差のない結果を得た.

一方, ダイス面の角度を変えた場合は 7,8 に示した.す なわち, 7 は半角 $60^{\circ}$ の凹面をるつダイスを使用した場合 で， 8 は逆に半角 $60^{\circ}$ の凸面をるつダイスを用いた場合の 結果であるが，凹面ダイスによる押出し压は凸面ダイスを 用いた場合より約 $10 \%$ 高い。このようにダイスの形状や 材質はSAP の押出し压にはたいした影響を扣よぼさない ことが明らかにされた．しかしつぎにのべるよ5にダイス の形状は押出し材に発生する亀裂とは密接な関係がある.

\section{8. 押出しダイスの形状と押出し材に 発生する亀裂の関係}

$\mathrm{SAP}$ はとの酸化物含有量が増加するにともなつて嘱く なりまた脆くなることはすでによく知られているとおり で，それに準じて押出し压も増加するが，とくに酸化物含 有量が 15 wt \% をこえると，押出し材全面にわたつて著し い亀裂が発生することが，打う打うにして認められた。

Photo. 2 は酸化物含有量 $15.8 \mathrm{wt} \%$ の素材を押出し比 $10: 1,500^{\circ} \mathrm{C}$ で押出した直径 $24 \mathrm{~mm}$ の SAP の写真であ る. (a) は flat die を使用した場合で, 押出し材の全長に わたつて著しい亀裂を生じた. しかしダイス半角 $45^{\circ}$ の凹 面ダイスを用いると (b) に示したように亀裂の数は著しく 減少する。 また，さらに半角の大きい $30^{\circ}$ の凹面ダイスを

Table 6 Die profile and material relationship on extrusion pressure in various extrusion experiments.

\begin{tabular}{|c|c|c|c|c|c|c|c|}
\hline & $\begin{array}{l}\text { Oxide content } \\
(\text { wt } \%)\end{array}$ & Direct or indirect & Die profile & Ext.ratio & $\begin{array}{c}\text { Ext.temp. } \\
\left({ }^{\circ} \mathrm{C}\right)\end{array}$ & $\begin{array}{c}\text { Ext. speed } \\
(\mathrm{mm} / \mathrm{sec})\end{array}$ & $\begin{array}{c}\text { Ext.press } \\
\left(\mathrm{kg} / \mathrm{mm}^{2}\right)\end{array}$ \\
\hline $\begin{array}{l}1 \\
2 \\
3 \\
4 \\
5 \\
6 \\
7 \\
8 \\
9\end{array}$ & $\begin{array}{c}5.2 \\
\text { "' } \\
\text { " } \\
\text { "I } \\
\text { A1 Billet } \\
\text { "I } \\
8.3 \\
\text { " } \\
10.0\end{array}$ & $\begin{array}{c}\text { Indirect } \\
\text { " } \\
\text { " } \\
\text { " } \\
\text { " } \\
\text { " } \\
\text { " } \\
\text { " } \\
\text { " }\end{array}$ & 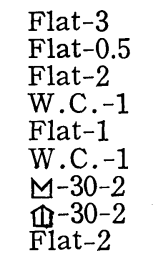 & $\begin{array}{r}5 \\
5 \\
10 \\
10 \\
5 \\
5 \\
10 \\
10 \\
10\end{array}$ & $\begin{array}{l}512 \\
505 \\
505 \\
507 \\
400 \\
395 \\
505 \\
508 \\
507\end{array}$ & $\begin{array}{r}13 \\
13 \\
11 \\
9 \\
10 \\
11 \\
5 \\
4 \\
3\end{array}$ & $\begin{array}{l}20.3 \\
20.0 \\
34.5 \\
37.0 \\
13.0 \\
13.6 \\
44.0 \\
40.0 \\
40.7\end{array}$ \\
\hline
\end{tabular}

Die material: $\left\{\begin{array}{l}\text { W-carbide }(W-10 \% \text { Co }) \\ \text { SKD }-4\end{array}\right\}$; Flat-3: Flat die bearing $3 \mathrm{~mm} ; \square-30-2: \square 30^{\circ}$ bearing $2 \mathrm{~mm}$

表中 1, 2 はともにflat dieで bearing length はとれぞ れ 3 扰よび $0.5 \mathrm{~mm}$ であるが，押出し压にはほとんど差が
用いると (c)のように亀裂発生は全く認められなくなつた。 この結果は押出し中の附加的せん断変形量とよく対応する 
と考えられる。すなわち，SAPのように高温で脆くなる合 金の押出しには附加的せん断変形量の最も少ないダイス形

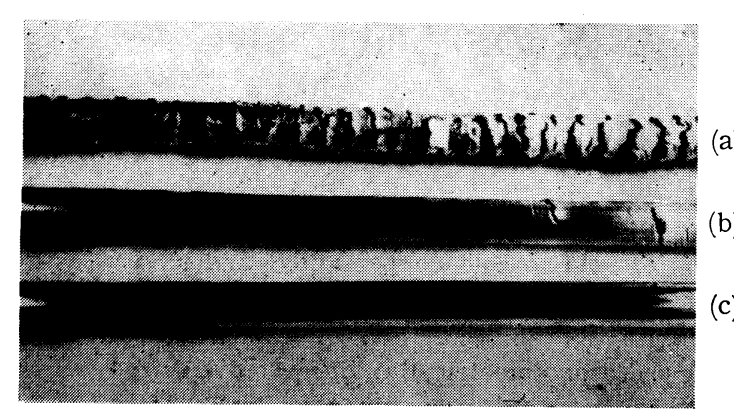

Photo.2 Surface of extruded S.A.P.bar with $15.8 \mathrm{wt} \%$ oxide. $(\times 1 / 5)$
(a) die angle $180^{\circ}$ (flat die)
(b) die angle $90^{\circ}$
(c) die angle $60^{\circ}$

状を選ら゙ことが望ましい。

なお，SAP の場合の押出し压は Table 5，6 に示したよ ろに, 押出し比の增加とともに上年するが, その点は他の 金属の場合と同様である.

\section{IV. 綿 括}

SAP の製造条件について研究を行ない，つぎの結果をえ た.

(1) 圧粉体の密度は粉末の酸化物含有量と圧粉圧力によ つて定まり，粉末の見かけ密度と直接関係がない。
（2）酸化物含有量 10～15 wt\% の Al 粉を成形する压力 としては約 $5 \mathrm{t} / \mathrm{cm}^{2}$ が適し，この場合 圧縮係数は約 3.0 3.5 で, 密度が $2.2 \sim 2.5 \mathrm{~g} / \mathrm{cc}$ 程度の圧粉体がえられる.

（3）前記の 压粉体を $500^{\circ} \mathrm{C}, 5 \mathrm{t} / \mathrm{cm}^{2}$ で高温压縮した場 合, 体積は約 $15 \%$ 減少する.この場合正常な 圧縮過程は 普通の金属円柱の圧縮過程と同じである.

(4) 前記高温王縮体の押出し圧は潤滑剤の種類, 押出し 速度により著しい影響をうけるが，それらを適当に選定す れば, 酸化物含有量 $11.6 \mathrm{wt} \%$ の場合でも $500^{\circ} \mathrm{C}$, 押出し 比 $15: 1$ の場合, 押出し圧を $40 \mathrm{~kg} / \mathrm{mm}^{2}$ 以下に下げるこ とができる.

(5) ダイスの材質やベアリング長さは押出し压に対して 大した影響を挹よぼさない。

（6）圧粉体を高温圧縮せず，そのまま押出せば押出し圧 は高温圧縮体を押出す場合に比べ約 $10 \%$ 低くなり，押出 し材の密度はほぼ同じになるが，欠陥が発生しやすく密度 も不均一になりがちである.

(7) ダイスの形状は押出し压には著しい影響を扤よぼさ ないが，欠陥の発生に密接な関係があり，その観点から附 加的せん断変形量を最も少なくするような形状のダイスが 適当である。

この研究は日本楽器製造株式会社の協力によつて行なわ れた. とくに試料の化学分析はすべて同社技術研究所で行 なつた.なお,この研究の遂行にあたり, 種々御指導, 御 援助をいただいた東北大学金属材料研究所大日方一司教 授, ならびに日本楽器製造株式会社技術研究所金属研究室 長 Dr-Ing. 執印智司氏に深く感謝の意を表します。 